THE JOURNAL OF TRANSPORT AND LAND USE http://jtlu.org

Vol. 6 No. 3 [2013] PP. 29-42 doi: 10.5198/jtlu.v6.i3.372

\title{
The implications of and institutional barriers to compact land development for transportation: Evidence from Bejing
}

\author{
Pengjun Zhao ${ }^{\mathrm{a}}$ \\ College of Urban and Environmental Sciences \\ Peking University
}

\begin{abstract}
Land use patterns are believed to affect transportation, while low-capacity land-use management is often seen as one of the primary institutional barriers to sustainable transport. Examining the case of Beijing, this paper aims to contribute more evidence in relation to these issues. Over the past decades China's megacities have witnessed a dramatic transition in land use from traditional compact development to sprawling development due to rapid urbanization. This study found that this transition has tended to increase car usage and thus worsen the emission of pollutants by transport in Beijing when growth of income and other socioeconomic factors are taken into account. It is apparent that compact land-use policies need to be reintroduced to reduce car use. However, there are several institutional barriers related to the reintroduction of compact development in the current context of transition from a centrally planned system to a market system in China's cities. In particular, increasing fragmentation in the realm of land-development management has created serious challenges to the implementation of compact land-development policies. Therefore, institutional capacity building is needed to enable compact land-use policies to control local sprawl and promote sustainable transport.
\end{abstract}

\section{Introduction}

In China between 2001 and 2011, the private vehicle fleet grew by an average of 25.4 percent annually to more than 100 million vehicles. In the same period, the transport sector's use of petroleum increased from 24.6 percent to 36.2 percent of total use, and it is projected to reach 47 percent in 2030. Cars accounted for 7 percent of domestic CO2 emissions, and this is forecast to increase because of the rapid process of motorization in China (World Bank 2007). Car use is also a major factor influencing air pollution in China's cities. The number of premature deaths related to traffic pollutants reached 140,000 in 2004 in China (Yao and Qin 2008). Pollutant emissions from transport are especially serious in the growing megacities due to rapid growth of vehicle kilometers travelled (VKT).

Land-use patterns, characterized by the five Ds (density, diversity, design, destination accessibility, and distance to transit), are believed to have important effects on private motorized travel (see Banister 1992; Banister et al. 1997; Loo and Chow 2008). Many empirical studies in developed countries have already found that urban sprawl on the urban fringe increases VKT (for example, Camagni et al. 2002; Cervero and Landis 1995). Therefore, land-use policies can be used to reduce energy-related $\mathrm{CO} 2$ emissions arising from urban transportation and improve local air quality (Ewing et al. 2007; Ewing and Rong 2008).

Many recent arguments have focused on compact land development, which has the features of higher density, diversity, walking- or bicycling-friendly design, high accessibility to destinations, and shorter distances to public transit services (Jenks et al. 2000). Compact development aims to achieve urban compactness through three processes: intensification, consolidation, or densification (Burton 2002). Compact development is believed to be associated with lower motorized travel and VKT than sprawling development (Transportation Research Board 2009). For example, a recent study conducted by Brownstone and Golob (2009) showed that a 40 percent increase in residential density is associated with approximately 5 percent fewer annual VKT after controlling for socioeconomic differences. Accordingly, land-use planning designed to promote compact development would have significant implications for the reduction of pollutant emissions due to transportation.

However, it must be acknowledged that claims about such implications are often criticized. One of the reasons for this is that conclusions about links between land use and transportation are still mixed (Ewing and Cervero 2010). Another reason is that compact policies are not always in the interests of all local governments, as the rejection by some municipal governments of land-use policies designed to control urban development testifies (Razin 1998). Thus, there is a dilemma confronting the implementation of land-control policies at the municipal level; in some ways local growth management will assist in the achievement of metropolitan and national en-

a pengjun.zhao@pku.edu.cn 
vironmental goals, but in other ways it will detract from this mission (Carruthers 2002; Chinitz 1990). In particular, when local benefits are the main concern of the local government, local decision making on growth, strengthened by political decentralization, can create challenges for municipal land-control policies. For example, urban limit (or urban growth-boundary) management, which is used to control urban sprawl, is often ignored by local governments, which are located within the limit boundary. One of the major reasons for this is that strict control of land development can cause economic opportunities to move to local governments located beyond the urban limit boundary. Such effects are called "spill-over" effects (Jun 2004).

A low capacity to implement certain land-use policies concerned with transport is seen as one of the primary institutional barriers to sustainable transport (Stough 2004; Stough and Rietveld 1997; Stough and Rietveld 2005). The rules and rule structures that guide both public and private action in this regard form various kinds of institutions (North 1990). There are usually four kinds of institutions that play a role in the land use-transport connection: (i) formal institutions, which are rules codified by laws, regulations, administrative orders, and administrative statues; (ii) informal institutions, which are deeply embedded values, norms, customs, and traditions; (iii) governance institutions, which are rules, including minor laws, administrative orders, and regulations at the local level reflecting the preferences of local stakeholders and decision making; and (iv) resource allocation institutions, which are made up of the action and behavior patterns of a diversity of actors in the decision-making environment, ranging from government agencies to firms and nonprofit organizations. The present study addresses the formal and governance institutional factors in its discussion of the implications of compact land policies.

Previous research suggests that the institutional barriers to land-use management with regard to transport may be more obvious in transition countries such as China, which is still in the process of transforming from a centralized planning system to a market system (Zhao 2011). Urban land development in China's megacities has undergone dramatic transition in the past decades. Before the 1980s, the development of land in these cities was characterized by compact land development, with most developments being self contained and including all of the main urban functions within the boundary of the site. Self-contained work units, or danwei (Bjorklund 1986), were typical of this development. These work units usually included employment, housing, and living facilities in one place surrounded by walls, the land use within the unit being highly mixed and dense. These work units constituted the basic fabric of China's cities, with each city composed of thousands. Another kind of compact development is the self-sufficient com- munity (ju zhu qu), made up of a basic social "cell" with housing and living facilities - for example, a post office, hospital, restaurants, and food markets. During the 1970s, many selfsufficient communities were built under the socialist principle of "convenient for daily life" (fang bian sheng huo). After the 1980s in China, land use for most new developments in the suburbs led to urban sprawl (Ma 2004; Zhao, et al. 2009a), which is characterized by dispersed industrial sites, sprawling gated communities, and huge motorway projects in the suburbs. Most of these sprawling developments are illegal (Zhao, et al. 2009a). Urban sprawl and illegal developments in China's cities are mainly attributed to the increasing fragmentation of land-development management in the context of transformation from a centrally planned system to a market system. In particular, local government autonomy and increased financial responsibility were the major drivers of the sprawling development (Zhang 2000).

Some studies argue that the transition in land use in China's megacities is one of the major factors increasing the overall length of trips made by vehicles (Li 2006; Zhao 2010). It is also believed that land-use policies can be used to reduce transport carbon emissions if they can efficiently encourage compact development (Zhao and Lu 2009). However, two major issues are still raised in relation to the implications of compact development polices for transport in China. One is that the empirical evidence for the effects of compact land use on individual travel choices and options in Chinas cities is still insufficient. The other is that little is known about the efficient application of compact land-use policies for the promotion of sustainable transport. A few studies have already argued that the declining capacity in land-use management is one of the vital institutional barriers to achieving sustainable transport in China's cities (e.g., Zhao and Lu 2010).

This paper aims to address these two issues. First, it will examine the challenges created by new land-development trends on the urban fringe with respect to motorized travel, and thus reveal the implications of compact land-use policy with respect to the reduction of private motorized travel and local carbon emissions. Second, the paper will discuss the institutional barriers to the implementation of compact land use in the context of political transition.

The analysis below consists of five sections. Following this introduction, Section 2 will introduce traditional compact land development in Beijing, and Section 3 will analyze the changes in the forms of land development on the urban fringe of Beijing and their impact on motorized travel patterns. Section 4 will present the evidence for the impact of land use on car use for the journey to work using data from a household survey, with car mode choice being estimated by a multinomial 
logit model. The policy implications will be discussed in Section 5 and conclusions drawn in Section 6.

\section{The tradition of compact land develop- ment in Bejing}

Beijing is China's capital. It has a land area of 16,808 square kilometers. In 2009, its total population was 16.8 million (Beijing Statistic Bureau, various years), and it is forecast that the city's population will reach 18 million in 2020 . The city is divided into four zones: the central urban areas, inter-suburban areas, outer suburban areas, and ecological conservation areas (see Figure 1). This study focuses on the central urban and inter-suburban areas because these two zones accounted for 69 percent of the total number of households and 74 percent of the total number of employees in Beijing in 2008. Furthermore, it is mainly in the inter-suburban areas that urban expansion has occurred in Beijing since the 1980s. The central urban areas and inter-suburban areas consist of four zones, according to the Beijing City Master Plan 2004-2020 (Beijing Institute of Urban Planning and Design 2004). They are the old city, the mixed urban area, the peripheral constellations, and the urban fringe areas.

Land development in Beijing has maintained the longstanding doctrine of containing urban expansion and using land highly efficiently through compact land development (Table 1). The implementation of compact land development can be seen to have occurred in two stages in Beijing. The first stage was the period before the 1980s. After 1949, when the
People's Republic of China was founded, a strict, centrally planned system was constructed, and it played a dominant role in all national economic and social activities, including land development and management. During this stage, two forms of compact development were implemented in China's cities, including Beijing. One was the development of self-contained work units, or danwei, in which housing and other facilities could be found alongside productive activities (Bjorklund 1986; Li 1993; Lu 1989). Each danwei had full responsibility for land development within its walls, including the site plan, the design of buildings, investment in development, construction of buildings, distribution of houses, and maintenance of buildings. With respect to urban function, danwei tended to be "self-sufficient subcities" (Xie and Costa 1993, p. 106), where travel distance and duration were short, and trips were undertaken on foot or by bicycle.

As introduced above, the second form of compact development was self-sufficient communities (ju zhu qu). Before the 1980s these self-sufficient communities were the basic living cells of a city, usually including housing alongside other facilities such as post offices, markets, shops, clinics, etc., designed to satisfy the inhabitants' daily needs, according to the principle of convenience for daily life (fang bian sheng huo). Land development in these self-sufficient communities was managed by the municipal government.

After the 1980s, compact development in Beijing entered a second stage, focusing on the curtailing of urban expansion and the enhancement of highly efficient land use, as rapid urban expansion, stimulated by the economic boom and

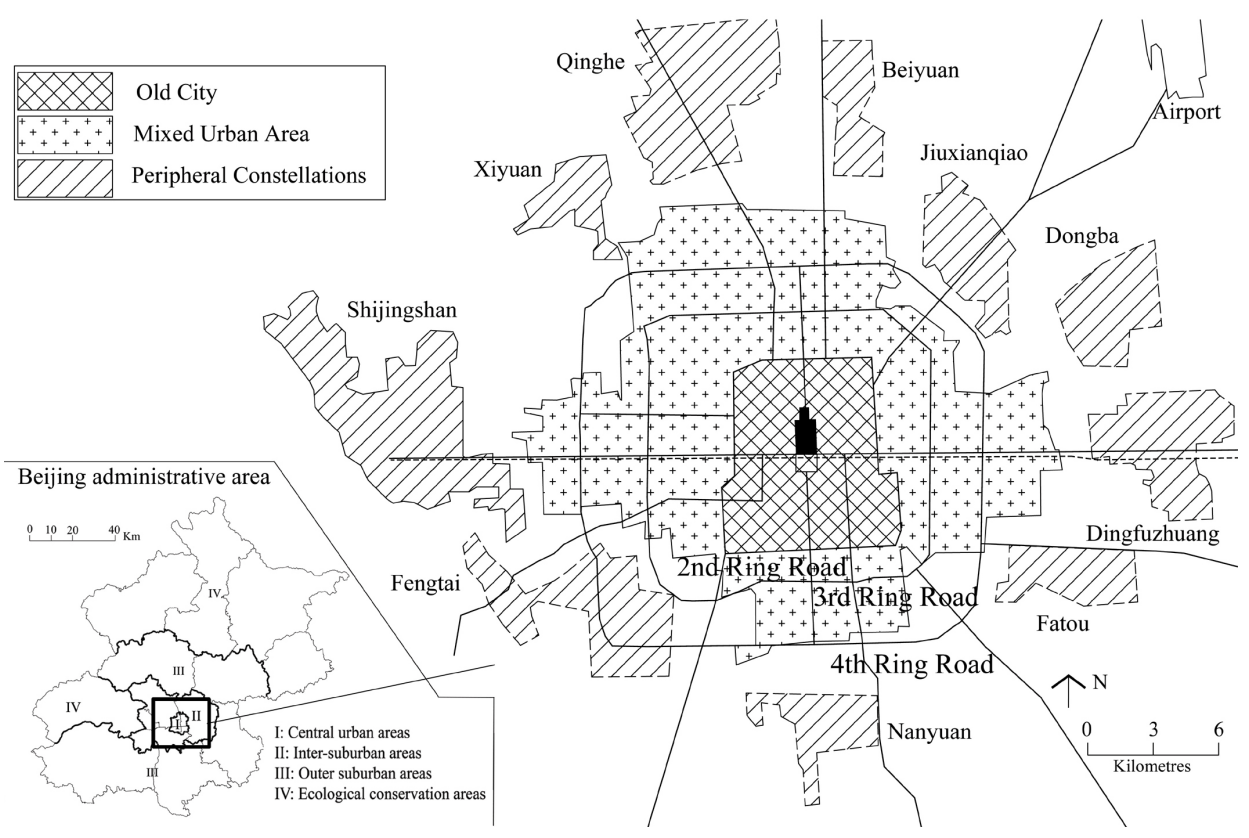

Source: Author, edited from Beijing Institute Urban Planning and Design, 1993.

Figure 1: Beijing urban spatial structure and the areas studied in this paper. 
rural-urban migration, had turned a huge amount of rural agricultural land into urban areas. During the 1990s, the loss of agricultural land was 4.78 times greater than the rate of local population growth in China. In Beijing, the built-up areas increased six-fold, from 180.9 square kilometers to 1085 square kilometers between 1979 and 2004. In response, the central government created strict and clear strategies to limit urban expansion and protect agricultural land in rural areas. Compact land development was one of the most important of these. It focused on the control of land transition from farmland to urban land in the suburbs and encouraged compact patterns of land use, characterized by high-density, concentrated physical forms, mixed land use and a high level of local jobs-housing balance. Compared with the model of compact development in the first stage, that of the second stage was implemented through formal means, such as acts and regulations. For example, according to the first City Planning Act (1989), land development permission on the urban fringe of large cities, including Beijing, is strictly limited.

Compact land-development policies were enacted at the national level and are still implemented in a top-down manner-from the macro (national, provincial, and municipal) to the micro (town and new communities) levels. Municipal governments, which are representatives of the national govern- ment, play a dominant executive role in implementing these policies. Local governments in China's cities usually include districts, counties, towns, street areas (jiedao), and rural villages. However, local governments at the district, county, town, and community committee levels have a very limited say in municipal policymaking.

Since the 1980s, a decentralized-concentration strategy has been implemented in Beijing to promote compact land use on the urban fringe (Zhao et al. 2010). One of the aims of the strategy was to encourage clustered and compact development in suburban planned areas, also called peripheral constellations. In the terms of the decentralized-concentration strategy, 10 peripheral constellations were to be located outside the central city area and connected to the center by a radial road system (Figure 1). These peripheral constellations were to focus on attracting new factories and population from the city. According to the strategy, further urban development in the suburban areas of Beijing would be concentrated inside the peripheral constellations and have a form of compact development, which is characterized by high-density, self-contained development and a concentrated physical pattern. Moreover, a greenbelt, located between the city center and the peripheral industrial areas, was designed to act as a buffer, restricting further growth and development in the mixed urban areas.

Table 1: Policies of compact land development in China.

\begin{tabular}{|l|l|l|}
\hline \multicolumn{1}{|c|}{ Periods } & \multicolumn{1}{|c|}{ Compact land use policies } & \multicolumn{1}{|c|}{ Implementations of policies } \\
\hline Before 1980 & Danwei system & $\begin{array}{l}\text { Development in danwei is managed internally } \\
\text { Self-sufficient communities managed by local community } \\
\text { committees that were branches of the municipal government }\end{array}$ \\
\hline $1980-1990$ & $\begin{array}{l}\text { Limiting urban expansion of large cities } \\
\text { Strictly protecting farmland in the suburbs } \\
\text { Efficient use of urban land } \\
\text { Greenbelt management } \\
\text { Development location management }\end{array}$ & $\begin{array}{l}\text { Land Management Act (1986) } \\
\text { City Planning Act (1989) } \\
\text { The national management of land categories (1990) } \\
\text { The primary farmland protection system (1990) } \\
\text { The land use change registration system (1990) } \\
\text { The new development permission system (1990) }\end{array}$ \\
\hline $1990-2000$ & $\begin{array}{l}\text { Limiting the total amount of land developments } \\
\text { Intensive and high-density land use } \\
\text { Concentrated industrial developments } \\
\text { Urban redevelopment and infilling development }\end{array}$ & $\begin{array}{l}\text { The National Land Use Plan (1992) } \\
\text { Amendment to the Land Management Act (1999) } \\
\text { The National Urban Land Use Classification and Planning } \\
\text { Standard (1990) } \\
\text { The National Residential Areas Planning Criterion (1994) } \\
\text { Developable land quota system (1998) }\end{array}$ \\
\hline After 2000 & $\begin{array}{l}\text { Controlling the total amount of housing development } \\
\text { Requirements on minimum net density of households } \\
\text { Requirements on minimum density of the residential } \\
\text { floor area } \\
\text { Encouraging intensive land use by land rent and land } \\
\text { tax management }\end{array}$ & $\begin{array}{l}\text { Land Management Act (second Amendment) (2004) } \\
\text { The Prescriptions to Intensify the Key Issues of Land Control } \\
\text { (2006) } \\
\text { The Prescriptions to Restructure Housing Supply and Stabi- } \\
\text { lize Housing Prices (2006) } \\
\text { Urban and Rural Planning Act (2007) }\end{array}$ \\
\hline
\end{tabular}




\section{New trends in land use on the urban fringe of Beijing}

Beijing has been undergoing rapid urban expansion stimulated by suburbanization since the 1980s (Zhou and Ma 2000). In Beijing, although rapid income growth and automobile manufacturing policy are important factors influencing total VKT, in the current process of rapid urbanization, the effects of new trends in land development, in terms of increasing the amount of travel by private vehicle, must be acknowledged. There are three main new trends in land development in Beijing. The first is urban sprawl. The second is the dramatic rise in the development of motorways in the suburbs and the third is low-density gated communities based on a new style of urban design.

\subsection{Urban sprawl on the urban fringe}

After 2000, 10 planned peripheral constellations in the intersuburban areas started to shape Beijing into a polycentric urban form (Ma 2004). However, urban sprawl can still be seen across the suburbs of Beijing (Deng and Huang 2004; Jiang et al. 2007; Zhao et al. 2009b). According to Ewing (1997), there are two kinds of urban sprawl: density-based sprawl and spatial-structure-based sprawl. Urban sprawl in Beijing is also characterized by these two forms, with spatial-structure-based sprawl in Beijing apparent in the city's scattered and dispersed development. Between 1990 and 2000, the physical forms of land use indicate an obvious increase in scattered development in Beijing. Many dispersed developments occurred outside the planned peripheral constellations, particularly in the outer suburban areas (see Figure 2).

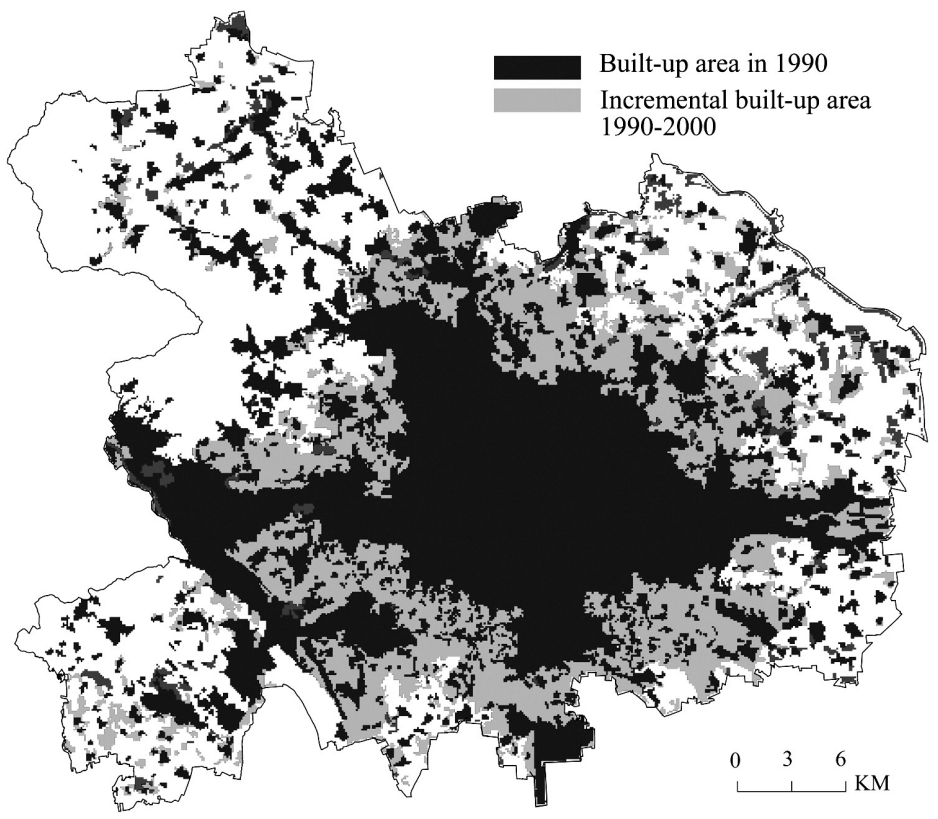

Density-based sprawl is clearly evidenced by decreases in density that have occurred during the current urban expansion process. Between 1990 and 2001, when there was radical urban expansion, the urban population density decreased from about 157 persons per hectare in 1990 to 115 persons per hectare in 2000. Many low-density gated communities have been developed on the urban fringe. "Low-density housing" here refers to housing with a density below 80 households per hectare (Wan Fang Co. 2001). While this may be higher than that in North America and Western Europe, it is much lower than the average density of 350 households per hectare in the central urban area of Beijing. The total floor area of low-density housing is equivalent to 22 percent of the total housing developed in the suburban areas of Beijing.

The low-density gated communities often have large-sized houses, with the average floor area of houses in these communities 120 square meters, eight times that of a house in other communities. Moreover, the land area of low-density gated communities is also usually large, with each of the low-density communities having on average a total floor area of 300,000 square meters (around 2500 households).

A low level of mixed land use is another feature of urban sprawl in Beijing. Since the end of the 1990s, land development on Beijing's fringe has faced a new trend: a dramatic separation of industrial development and residential development. Such developments are occurring against the backdrop of a process of industrialization and marketization. In the process, local governments are focusing on local revenue-enhancing development, in particularly, industrial development. Hundreds of industrial parks were developed in the suburbs of Beijing after the 1980s, their number reaching 470 by the end of 2003 , occupying more than 570 square kilometers of land (Zhao et al. 2010). The largest industrial park is the Beijing Economic Technological Development Area, which has a land area of 46.8 square kilometers. Most industrial parks have been developed by local district, county, town, or village governments rather than by the municipal government (in 2003, 76 of the 470 industrial parks were developed by municipal governments). As a result, the industrial parks have been scattered across all suburban areas and have caused serious urban sprawl.

In the meantime, real estate developments also grew quickly in the suburbs due to housing market reforms and growth of the population. Private developers began to supply housing according to market rules, and thousands of commercial housing communities were developed along main roads in the suburbs. Most of these communities are completely separated from industrial sites, except for a few large municipal industrial parks. These new communities also lack commercial land use and public service facilities such as schools, clinics, and daily

Source: Beijing Land and Housing Management Bureau, various years.

Figure 2: Expansion of built-up areas in Beijing (1990-2000). 
markets. In other words, there is a low level of mixed land use.

All these features of urban sprawl would have negative effects on transport-related emissions in two ways. First, they result in long-distance travel, in particular, travel between the city center and suburban areas. Second, they create problems for the provision of public transport and thus result in an increase in the number of trips taken by private vehicles.

\subsection{Transport investment in the suburbs}

Since the end of the 1990s, huge and expensive transport projects have dominated urban development in the suburbs of Beijing, with the total length of roads increasing from 2441 to 6971 kilometers between 1999 and 2010 (Figure 3) and the average annual growth rate reaching 10.4 percent. Of the roads, motorways accounted for 63.2 percent of the growth, connecting the city center with the suburban new towns, the suburban areas, the rural areas, and other cities outside Beijing (BSB, various years). Rapid extensions of motorways in the suburbs have played a key role in economic growth and urban expansion. However, they are also a major cause of urban sprawl across the whole urban fringe of Beijing. Many scattered industrial sites and residential buildings have been developed along these motorways. As a result, the drastic amount of investment in roads has further increased VKT and created more dependence on car use.

Figure 3 also shows that there was a rapid growth in metro lines, the total length of which increased from 54 to 324 kilometers between 1999 and 2010 (BSB, various years). This rapid development of the metro into the suburbs was intended to meet the increasing mobility demand caused by suburbanization and also reduce private motorized travel and mitigate traffic congestion in the city center. However, extreme overcrowding (the number of passengers in a carriage may be four

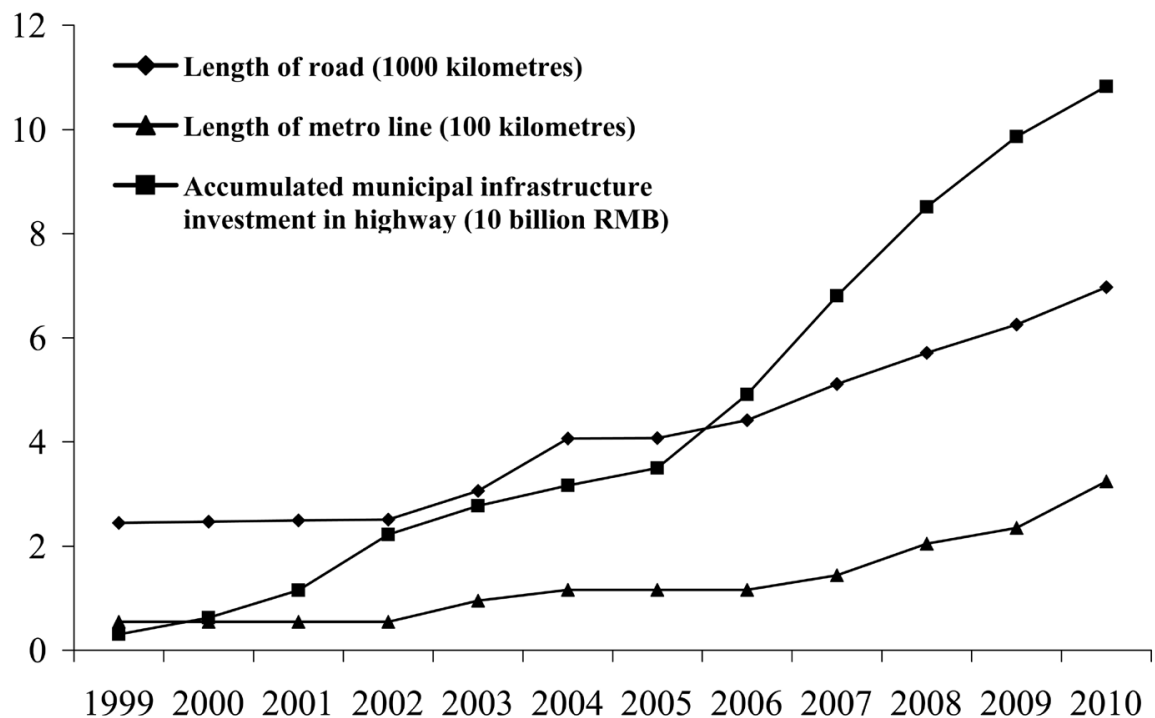

Source: Beijing Land and Housing Management Bureau, various years.

Figure 3: Transport investment in Beijing (1990-2009).
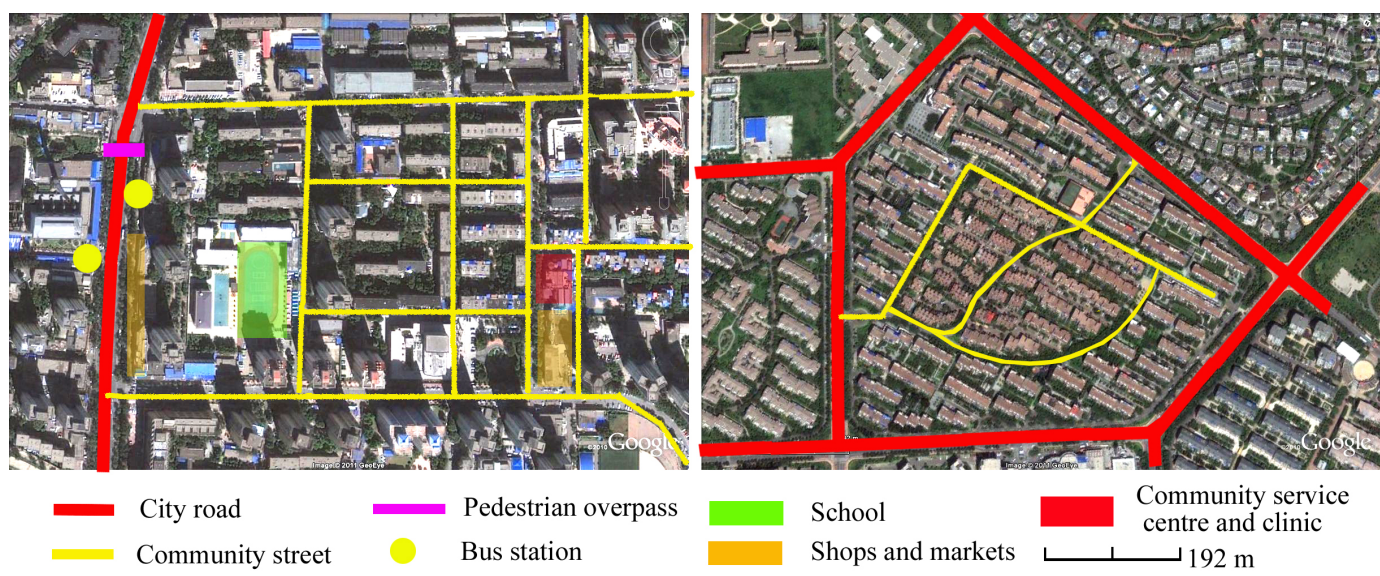

Figure 4: Comparison of traditional compact communities and new low-density communities in Beijing. 
or five times greater than the designed capacity of the carriage during peak hours) on the metro and growing VKT reveal that the development of metro lines alone would have a very limited effect on the reduction of overall transport emissions. Other policies, in particular, land-use planning, must be integrated to control the total travel demand.

\subsection{Urban design of the community}

The urban design of a community has an important influence on transport at the micro level. As mentioned above, before the 1990s a traditional community in Beijing was characterized by compact development, with housing located alongside public facilities and other daily facilities. External travel demand was low as most reasons for travel were addressed within the community. These traditional communities can be seen as selfsufficient. However, housing ownership within the traditional community was partly private and managed by an agent of the state, for example, as part of a state-owned enterprise (danwei), by a housing department of the municipality or by the local district government.

Since the reforms of the 1980s, China's housing market has been undergoing an obvious transformation (Chow 2007; Wei 2001). In the housing reform process, the socialist, welfare-oriented housing system has been transformed into a market-oriented system through the privatization of housing ownership (Huang 2004; Huang and Clark 2002; Wang and Murie 1999). These reforms led to great changes, not only in housing supply but also in the spatial pattern of the building stock. Private developers replaced the state-owned enterprises and government and have now become a major supplier of housing. New forms of urban community have now emerged across Beijing. Generally, the urban design of a community now focuses on marketable and profitable development. Most of the new communities on the urban fringe are characterized by lower density and greater use of land for roads and parking. In the city center, new communities are often of higher density due to the high land prices. Moreover, new communities, both in the city center and in the suburbs, use less land for public facilities and other services. Low accessibility to schools, clinics, sport parks, post offices, and public transport in these new communities has led to many more motorized trips on the urban fringe of Beijing. Figure 4 provides a comparison of a traditional compact community and a new low-density community in Beijing.

This traditional compact community is part of a xi luo yuan, which is a form of community developed in the 1980s. It has an average gross floor area ratio of 1.72 and a residential density of 718 persons per hectare, with nearly all daily facili- ties and services located in the community. These communities were also well serviced by bus and pedestrian facilities. The new form of low-density community is called Jindi gelin xiaozhen, first developed in 2003. The particular community shown here has a residential density of 240 persons per hectare, one-third of the traditional compact community. The land in the community is mainly used for real estate development and there are no local shops, markets or clinics. There is also a lack of basic urban services, such as schools and bus lines, the closest school being located 2.2 kilometers from the community. Such new low-density communities on the urban fringe of Beijing are thus typically dependent on the car.

\section{$4 \quad$ Evidence of the effects of land use on transportation}

\subsection{Method}

This section undertakes a quantitative analysis to substantiate the descriptive analysis of the impact of new trends in land use on transportation on the urban fringe of Beijing. The data used here were derived from a household interview survey conducted in Beijing in 2006. The quantitative analysis in this paper used 370 employed respondents living on the urban fringe. There are two reasons why the study focused on the relationship between land use and transport on the urban fringe. First, the urban fringe is the most dynamic part of the city, where changes in urban development, land use, the road system, and facility supply can all be observed. It is on the urban fringe that most urban sprawl occurs. Thus, an in-depth analysis of the urban fringe can clearly reveal the impact of land-use patterns on commuting in the process of rapid urban expansion. Second, Beijing has witnessed rapid residential suburbanization in the last decade. However, most jobs are still concentrated in the central areas. This has resulted in huge commuting traffic volumes between the suburbs and the city center during peak hours. Such traffic volumes have become one of the major factors contributing to congestion and air pollution in Beijing. In this context, a study that focuses on suburban workers' travel behavior can provide concrete evidence for the effects of landuse changes on congestion in Beijing.

This paper measures land-use patterns in terms of employment density, residential density, mixed land use, urban design of the community, transport development, and location of land development. The net density of employment and population is measured by the density of employment and population, respectively, in the sub-district in which a household lives. Mixed land use is indicated by the local jobs-housing balance, which is measured by the ratio of jobs to housing at the level of 
the sub-district in which a household resides. The urban design of the community is measured by the density of local streets and local shopping facilities within the community. The higher the density of the local streets, the more walking- and cyclingfriendly is the land use. Local shopping facilities are measured in terms of the amount of land used for markets, retail shops, and restaurants in the community divided by total land area. The degree of transport development is measured in two ways. First, car transport development is measured by the total length of the main roads in a range of 5 kilometers from the center of the community in which the household is located. The main road includes the motorway and the city's rapid access routes. Second, public transport development is calculated as the total number of bus or metro stations within a given service distance to the community. For public buses, the threshold service distance is $\mathbf{5 0 0}$ meters, for the metro it is $\mathbf{1 0 0 0}$ meters. Finally, the levels of bus and metro transport development for a community are integrated into one value, which is given a weight. The higher the value, the higher is the degree of public transport development associated with the household.

The location of residential development refers to the location characteristics of a community. It is indicated by the relative proximity of a location to workplaces. The regional location $\left(L_{i}\right)$ is measured by $L_{i}=\sum E_{j} \exp \left(-\beta d_{i j}\right)$, where $E_{j}$ is the employment size of sub-district $j$; $d_{i j}$ is the shortest road distance from the community $i$ where a household lives to the sub-district $j$; and $\beta$ is the parameter for the impedance function, which equals 0.3 in this study. The value of a regional location reflects the spatial relationship between housing development and economic development, including industrial and commercial development and transport investment. It is usually higher in compact development than in sprawling development.

Many studies have reported that individual and household socioeconomic characteristics can largely explain variations in commuting patterns (Frank and Pivo 1994; Stead 2001). Without controlling for such socioeconomic factors, a study that attempts to examine the impact of land use on commuting will not provide an adequate understanding of the relationship between land use and commuting patterns. In this study, four variables were selected to indicate individual and household socioeconomic characteristics. They were the worker's gender, annual household income, household composition (number of earners), and the worker's occupation. Table 2 presents the descriptive statistics for the independent variables.

\subsection{Regression analysis}

The multinomial logit (MNL) model was applied to estimate workers' travel mode choice. The results of the analysis presented in Table 3 indicate that an individual worker's travel mode for the journey to work would be significantly influenced by land-use patterns. For car users, the coefficients of residential density, employment density, and the jobs-housing balance are all negative, which means that when workers live within a subdistrict with a lower degree of jobs-housing balance, employment density, or population density, there is a higher likelihood that they will choose to commute by car rather than public transport.

The Exp (B), which indicates the odds ratio of travel by car over the reference travel mode (that is, commuting by public transport), has a value of 0.9811 for residential density, meaning that the odds of choosing to commute by car are slightly lower than choosing to commute by public transport when population density is higher. In areas with lower employment density, workers tend to choose the car rather than public transport as their mode of travel to work. Similarly, in a zone with a low jobs-housing balance, the likelihood of choosing to commute to work by car is $1.8(1 / 0.5442)$ times higher than choosing to commute by public transport. These results suggest that low residential density, low employment density, or low mixed land use would increase motorized travel. The results are consistent with many previous studies (e.g., Banister 1997; Camagni et al. 2002; Cervero and Landis 1995).

Table 3 shows that the probability of a worker choosing to commute by foot, bicycle, or other transport mode will become higher when the worker resides in an area with higher residential density, higher employment density, or a higher jobs-housing balance. For example, the value of the Exp (B), 1.4355 , indicates that when the jobs-housing balance increases by 10 percent, the odds ratio of travel by foot, bicycle, or other transport mode would increase by 36 percent. Similarly, higher residential density and employment density would enhance the probability of choosing foot, bicycle, or other transport mode. These results are consistent with some previous studies (Banister and Watson 1997; Banister et al. 1997).

It is interesting to note that there are differences in the effects of density on a worker's mode choice between employment density and residential density. Employment density exerts slightly more influence than residential density, according to the values of their coefficients (the former is -0.0191 , while the latter is -0.0205). This is consistent with a recent study by Chen et al. (2008) of the New York metropolitan region.

The results in Table 3 show that when a worker lives in a sub-district with a lower degree of public transport develop- 
Table 2: Descriptive statistics for the independent variables.

\begin{tabular}{|l|l|l|}
\hline Variable & Mean & Standard deviation \\
\hline Household annual income (10,000 RMB) & 3.5 & 11.9 \\
\hline Residential density (100 persons/ha.) & 1.01 & 2.27 \\
\hline Employment density (100 jobs/ha.) & 0.42 & 1.56 \\
\hline Jobs-housing balance & 0.4 & 1.1 \\
\hline Local streets density $\left(\mathrm{km} / \mathrm{km}^{2}\right)$ & 5.5 & 8.2 \\
\hline Local shopping $(\%)$ & 5.1 & 17.4 \\
\hline Public transport development (units) & 1.7 & 5.9 \\
\hline Main roads development $(\mathrm{km})$ & 7.9 & 12.6 \\
\hline Regional location & 1.8 & 3.6 \\
\hline
\end{tabular}

Table 3: Multinomial logit (MNL) model analysis for workers' travel mode $(\mathrm{n}=370)$.

\begin{tabular}{|c|c|c|c|c|c|c|}
\hline & \multicolumn{3}{|c|}{ Car $^{\mathrm{a}}$} & \multicolumn{3}{|c|}{ Foot, bicycle or other transport mode ${ }^{\mathrm{a}}$} \\
\hline Independent variables & B & Wald & $\operatorname{Exp}(B)$ & B & Wald & $\operatorname{Exp}(B)$ \\
\hline Intercept & 4.0502 & 0.0023 & & 6.9127 & $27.119^{* * *}$ & \\
\hline \multicolumn{7}{|l|}{ Features of land use } \\
\hline \multicolumn{7}{|l|}{ Density } \\
\hline Residental density & -0.0191 & $1.4531^{\star}$ & 0.9811 & 0.0106 & $1.4904^{*}$ & 1.0107 \\
\hline Employment density & -0.0205 & $1.1994^{\star}$ & 0.9797 & 0.0772 & $2.7113^{\star}$ & 4.3807 \\
\hline \multicolumn{7}{|l|}{ Mixed land use } \\
\hline Jobs-housing balance & -0.6084 & $3.5193^{\star *}$ & 0.5442 & 0.3615 & $3.0086^{* *}$ & 1.4355 \\
\hline \multicolumn{7}{|l|}{ Urban design of the community } \\
\hline Local streets density & -0.0275 & 0.0641 & 0.9729 & 0.7512 & $1.6085^{\star}$ & 2.1195 \\
\hline Local shopping & -0.2106 & 0.7132 & 0.8101 & 1.2859 & $1.8037^{\star}$ & 3.6179 \\
\hline \multicolumn{7}{|l|}{ Transport development } \\
\hline Public transport development & -1.5703 & $2.0155^{\star}$ & 0.2080 & 1.1473 & $2.0034^{*}$ & 3.1497 \\
\hline Main roads development & 0.2156 & $3.5938^{\star *}$ & 1.2406 & 0.0621 & 0.3148 & 1.0641 \\
\hline \multicolumn{7}{|l|}{ Location of land development } \\
\hline Regional location & -0.2644 & 0.8217 & 0.7677 & 1.0754 & $1.5114^{*}$ & 2.9312 \\
\hline \multicolumn{7}{|l|}{ Socioeconomic factors } \\
\hline Male & 0.1854 & 0.6164 & 1.2037 & -1.8096 & $3.6632^{* *}$ & 0.1637 \\
\hline Two earners & 0.1231 & 0.1760 & 1.1310 & -0.1098 & 0.6421 & 0.8960 \\
\hline Low income & -0.3754 & 0.9115 & 0.6870 & -0.6763 & $1.4843^{*}$ & 0.5085 \\
\hline Middle income & 1.6526 & $1.1179^{*}$ & 5.2205 & -1.3241 & $1.6001^{*}$ & 0.2660 \\
\hline $\begin{array}{l}\text { Low-skill professional or office } \\
\text { worker }\end{array}$ & -1.8322 & $3.6154^{* *}$ & 0.1601 & 0.0804 & 0.0027 & 1.0837 \\
\hline $\begin{array}{l}\text { Middle or high-level profes- } \\
\text { sional or management worker }\end{array}$ & 2.6876 & $4.4439^{* * *}$ & 14.6964 & -1.4911 & $2.8972^{\star}$ & 0.2251 \\
\hline \multirow[t]{2}{*}{ Model Fit Information } & \multicolumn{3}{|c|}{-2LL (-2 times Log Likelihood) } & Chi-Square & Sig. & \\
\hline & 396.1 & & & 277.5 & $\mathrm{p}<0.001$ & \\
\hline \multicolumn{7}{|c|}{ PCP (percentage correctly predicted): 69.8} \\
\hline \multicolumn{7}{|c|}{ aThe reference category is "commute by public transport." } \\
\hline
\end{tabular}


ment, there is a higher likelihood that he or she will choose to commute by car rather than choosing to commute by public transport. The $\operatorname{Exp}(\mathrm{B}), 0.2080$, indicates the odds ratio of traveling by car compared to public transport, revealing that the probability of choosing to commute by car is a fifth that of choosing to commute by public transport when the worker resides in a community that has higher public transport development. The results in Table 3 also show that when a worker lives in a sub-district with a higher degree of main road development there is a higher likelihood that he or she will choose to commute by car rather than choosing to commute by public transport. The results suggest that current huge and expensive motorway projects would stimulate further private motorized travel. This is often described in terms of an induced travel demand mechanism in the literature about land use-transport connections (Cervero 2002; Handy 2005).

Table 3 shows that a worker's travel mode for the commuting trip is significantly associated with two urban design elements. The probability of a worker choosing to commute by foot, bicycle, or other transport mode will become higher when the worker resides in a community with a higher local street density or higher level of local shopping facilities. It is interesting that the location indicator for residential development has significant effects on a worker's travel mode choice. The results in Table 3 indicate that a higher value for regional location would stimulate travel by foot, bicycle, or other transport mode.

\section{Discussion and policy implications}

The results of the above analyses show that the current new trends in land use in Beijing would have negative effects on the reduction of car usage for travel. In fact the new trends in land use would increase car usage for several reasons: urban sprawl characterized by dispersed and low-density development; declines in the degree of local mixed land use, particularly the low level of the local jobs-housing balance; and sprawling gated communities. All of these results suggest that policies designed to change land use would have major implications for the reduction of motorized travel and the improvement of air quality.

The form of land use may be affected by policies in a number of ways. However, in most cases, land-use planning and community design are the most common approaches, covering the set of policy instruments available to regulate and manage forms of land development and use in a broad sense. Land-use planning will have an impact on mobility through its effects on aspects of land-use patterns, including density, mixed land use, and distance to transport infrastructure, which determine housing and workplace locations, the distribution of urban facilities, and transport connections between various locations and activities. The above results demonstrate that density policies can be used to reduce VKT, as both higher residential density and higher employment density tend to encourage the public and non-vehicle modes and reduce car use. Similarly, policies that are focused on the enhancement of the jobs-housing balance would also efficiently reduce car use for commuting, as an increase of 10 percent in the jobs-housing balance is related to 36 percent growth of the odds ratio of travel by foot, bicycle, or another mode of transport other than the car. Community design affects travel behavior through microbuilt environments, including walking- and cycling-friendly street patterns, local shopping facilities, and public services. In summary, the land-use pattern defines the basic context and constraints on individual travel behavior (Banister 2008). The findings from Beijing provide evidence for this.

With respect to policy implications, the results indicate that there is a strong need to return to traditional compact land use in new suburban developments in China's cities to reduce traffic pollutants. Since the 1980s, land-use development in these cities has experienced an obvious transition, with sprawling development emerging and becoming a major form of land use (Fung 1981; Deng and Huang 2004). The traditional compact community in China's cities was characterized by high-density, self-contained development and mixed land use. Travel was dominated by walking and cycling within the community. However, in sprawling gated communities, land use is dominated by a low level of mixed use, in particular a shortage of basic urban services and facilities, including public transit services. Many communities have a much lower density than traditional communities. The results above show that these new trends in land use and design increase the risk of car dependence. A return to compact development could play an important and positive role in reducing VKT, even though car use is still affected by other socioeconomic factors.

At the same time, however, it must be noted that it will not be easy to return to compact development since its institutional context has changed dramatically in China's cities. There are several institutional barriers to the implementation of compact development aimed at sustainable transportation. Since the 1980s, China has been undergoing a transformation from a centrally planned system to a market system. This transformation has involved three contemporary and interrelated processes: decentralization, marketization and globalization (Chow 2007; Wei 2001). The process of decentralization has led to a dramatic rescaling of the relationship between the state, local jurisdictions, enterprises, and private developers (Shen 2005), with growing local autonomy and fiscal responsibility major factors influencing land-use changes (Zhao et al. 2009a). 
This has fostered urban sprawl on the urban fringe of Beijing. With greater autonomy in the decision-making process related to local growth, the local district and county governments have become increasingly powerful in relation to the pursuit of local social and economic development. As Wank (1999, p. 250) pointed out, local governments "have acquired greater administrative control over the market economy in their jurisdictions through new regulatory, taxation, and licensing powers." As a result, national and municipal government control over land development is often challenged by local developments, with the resulting urban sprawl occurring across the full extent of the urban fringe. This local-government-led sprawl in China's cities is obviously different from North American cities.

Urban sprawl due to local government policies has also created specific challenges in relation to the reduction of VKT in Chinass cities. According to Stough and Rietveld (2005), intergovernmental relations with respect to managing land use are a major institutional barrier to sustainable transportation, with power conflicts apparent among different government agencies in the sphere of urban development. In China, increasing decentralization is not only intensifying the conflict between the central government and local governments, but it is also increasing conflict between local governments. Decentralization has increased competition rather than cooperation among local governments. Individual local governments are interested in attracting investment and concentrating development in their own administrative areas, and some local governments have relaxed control of land use (Shen 2005). As a result, land development at the level of local jurisdictions has caused a degree of disorder in new development across suburbs. This is consistent with the argument that local governments tend to implement municipal government policies designed to control urban growth according to the economic benefits they can achieve (Carruthers 2002; Chinitz 1990). The results of the above analysis suggest that scattered residential and industrial development across the suburbs would increase the need for motorized travel, in particular, by private vehicle.

Apart from the decentralization of the governance system, increasing market-oriented development is another challenge to the goal of compact development. Since the 1980s, market reforms in land development have opened up multi-scale forms of governance with multi-stakeholder arrangements (MSAs). In this system, market-led development, which is different from the traditional government-initiated development, is increasing and becoming a new force shaping land development on the urban fringe. Market-led development favors revenue-enhancing development, such as office buildings, retail and other high tax-yielding land use, in particular commercial housing development. As a result, local revenue-enhancing de- velopment could be at the expense of the degree of local mixed land use. The results above show that a low level of mixed land use would increase the demand for motorized travel.

The separation of land development management and transport infrastructure development management is another institutional barrier to the reduction of traffic emissions in China's cities. In the pre-reform era, before the 1980s, urban development was managed by a centrally planned system in which land development and transport development were highly integrated at the city level. The municipal committee of economic planning (ji hua jing ji wei yuan hui) was the only department involved, responsible not only for land-use development plans and transport development plans but also for the implementation of the plans. After the 1980s, transport development management was separated from land development during the process of decentralization. Transport development is still usually seen as a way of promoting the growth of regional GDP (gross domestic product), with the state and municipal governments jointly investing in this type of development. However, land development is now managed by municipal and local governments. In most cases, land-use planning is the responsibility of local government, for example, the land resource management department or the urban planning bureau. However, transport planning remains under the control of a municipal transport department and transport investments are often managed by the state. Consequently, land-use plans and transport development plans are usually inconsistent with each other regarding economic goals and social and environmental effects.

The separation of land use and transport development is not only reflected in plan-making processes but also in actual development activities, with land development at the local level (towns and villages) usually implemented much faster than municipal transport development because local governments generally do not hesitate when opportunities for land development arise. In addition, the location of land development is largely determined by local governments and investors, while transport-in particular, motorways and main roads-remains under the control of the municipal government. This is one of the major reasons why some gated communities are still isolated from the existing transport network.

\section{Conclusion}

In the rapidly growing megacities of developing countries, the growth in motorized travel has caused serious congestion in city centers and increased environmental problems due to carbon emissions and poor air quality. In China's cities, the current transition in land use from traditional compact develop- 
ment to urban sprawling development is a significant factor in the growth of car use and related air pollution, when the growth of income and other socioeconomic factors are taken into account. Land-use policies that reintroduce compact development would assist in reducing total VKT and have transport-related environmental effects. More positive effects would be achieved if compact land use were integrated with transport infrastructure development in the form of a public transit system.

However, it must be recognized that currently there are many institutional barriers to the implementation of compact land use in China's cities aimed at sustainable transport. First, intergovernmental relationships concerning the management of urban development have become weak. Second, political decentralization and the fragmentation of land development management are key factors stimulating urban sprawl. Third, the increase in revenue-enhancing development has created problems with mixed land use and hindered self-sufficient development. It appears that municipal compact land development policies can only be implemented efficiently by addressing local government economic interests. Finally, the separation of land use and transport development management is another institutional barrier to the reduction of car usage.

With regard to future policy, more attention should be paid to institutional innovations in land development management for transport. Stronger metropolitan development management should be enforced to enable the land management system to facilitate compact development on the urban fringe. Institution building, which attempts to establish an inter-organizational management setup for compact development in China's cities, is the primary step required to strengthen management capacity. In addition, more harmonious relationships between land use developments at the local level and transport investment by municipal governments should be addressed. The comprehensive management of land development permits, transport delivery, and housing provisions should also be introduced. In practice, compact developments should be integrated with transit-oriented developments, which are currently being encouraged in many of China's large cities.

\section{Acknowledgements}

The travel data used in this study came from a housing survey undertaken in 2001 by Professor Li Si-Ming from Hong Kong Baptist University and Professor John R. Logan from Brown University.

\section{References}

Banister, D. 1992. Energy use, transport and settlement patterns. In Sustainable Development and Urban Form, M. Breheny (ed.), 160-181. London: Pion.

Banister, D. 1997. Reducing the need for travel. Environment and Planning B 24(3): 437-449.

Banister, D. 2008. The sustainable mobility paradigm. Transport Policy 15(2): 73-80.

Banister, D., and S. Watson. 1997. Sustainable cities: transport, energy and urban form. Environment and Planning B 24(1): 125-143.

Bjorklund, E. M. 1986. The Danwei: Socio-spatial characteristics of work units in China's urban society. Economic Geography 62(1): 19-29.

Beijing Institute of Urban Planning and Design (BIUPD). 2004. Beijing City Master Plan (2004-2020), Beijing: Beijing Institute of Urban Planning and Design (BIUPD).

Beijing National Land Resource and Housing Management Bureau (BLHB). Various years. Beijing Land Readjustment Data. Beijing: Beijing National Land Resource and Housing Management Bureau.

Beijing Statistic Bureau (BSB). Various years. Beijing Statistic Yearbook (in Chinese: Beijing shi tong ji nian jian). Beijing: China Statistical Publishing House (in Chinese: zhong guo tong ji chu ban she).

Burton, E. 2002. Measuring urban compactness in UK towns and cities. Environment and Planning B 29(2): 219-250.

Camagni, R., M. C. Gibelli, and P. Rigamonti. 2002. Urban mobility and urban form: The social and environmental costs of different patterns of urban expansion. Ecological Economics 40(2): 199-216.

Carruthers, J. I. 2002. Evaluating the effectiveness of regulatory growth management programs. Journal of Planning Education and Research 21(4): 391-405.

Cervero, R. 2002. Induced travel demand: Research design, empirical evidence, and normative policies. Journal of Planning Literature 17(1): 3-20.

Cervero, R., and J. Landis. 1995. The transportation-land use connection still matters. Access (7): 210.

Chen, C., H. Gong, and R. Paaswell. 2008. Role of the built environment on mode choice decisions: Additional evidence on the impact of density. Transportation 35: 285-299

Chinitz, B. 1990. Growth management: Good for the town, bad for the nation? Journal of American Planning Association 56(1): 3-8.

Chow, G. C. 2007. China's Economic Transformation (2nd ed.). London: Blackwell Publishing Ltd. 
Deng, F. F., and Y. Huang. 2004. Uneven land reform and urban sprawl in China: The case of Beijing. Progress in Planning 61(3): 211-236.

Ewing, R. 1997. Is Los Angeles-style sprawl desirable? Journal of the American Planning Association 63(1): 107-126.

Ewing, R., K. Bartholomew, S. Winkelman, J. Walters, and D. Chen. 2007. Growing Cooler: The Evidence on Urban Development and Climate Change. Washington, DC: Urban Land Institute.

Ewing, R., and R. Cervero. 2010. Travel and the built environment. Journal of the American Planning Association 76(3): 265-294.

Ewing, R., and F. Rong. 2008. The impact of urban form on U.S. residential energy use. Housing Policy Debate 19(1): $1-30$.

Frank, L. D., and G. Pivo. 1994. Impacts of mixed use and density on utilization of three modes of travel: Single occupant vehicle, transit, and walking. Transportation Research Record 1466: 44-52.

Fung, K. I. 1981. Urban sprawl in China: Some causative factors. In Urban Development in Modern China, L. J. C. Ma and E. W. Hanten (ed.), 194-221. Boulder: Westview Press.

Handy, S. 2005. Smart growth and the transportation-land use connection: What does the research tell us? Urban Studies 28(2): 146-167.

Huang, Y. 2004. The road to homeownership: A longitudinal analysis of tenure transition in urban China (1949-93). International Journal of Urban and Regional Research 28(4): 774-795.

Huang, Y., and W. A. V. Clark. 2002. Housing tenure choice in transitional urban China: A multilevel analysis. Urban Studies 39(1): 7-32.

Jenks, M., E. Burton, and K. Williams, eds. 2000. The compact city: A sustainable urban form? London: E \& FN Spon.

Jiang, F., S. Liu, H. Yuan, and Q. Zhang. 2007. Measuring urban sprawl in Beijing with geo-spatial indices. Journal of Geographical Sciences 17(4): 469-478.

Jun, M. J. 2004. The effects of Portland's urban growth boundary on urban development patterns and commuting. Urban Studies 41(7): 1333-1348.

Li, B. 1993. Danwei culture as urban culture in modern China: The case of Beijing from 1949 to 1979. In Urban Anthropology in China, G. Guldin and A. Southall (eds.). Leiden, The Netherlands: E. J. Brill.

Li, H. 2006. Study on the urban form, traffic pattern and resident traffic mode. (In Chinese). PhD Thesis, Southeast University Nanjing, China.
Loo, B. P. Y., and A. S. Y. Chow. 2008. Changing urban form in Hong Kong: What are the challenges on sustainable transportation? International Journal of Sustainable Transportation 2(3): 177-193.

Lu, F. 1989. The work unit: a unique form of social organization. Chinese Social Sciences 1: 1-17.

Ma, L. J. C. 2004. Economic reforms, urban spatial restructuring, and planning in China. Progress in Planning 61(3): 237-260.

North, D. C. 1990. Institutions, Institutional Change and Economic Performance. Cambridge, UK: Cambridge University Press.

Razin, E. 1998. Policies to control urban sprawl: Planning regulations or changes in the "rules of the game?" Urban Studies 35(2): 321-340.

Shen, J. 2005. Space, scale and state: reorganizing urban space in China. In Restructuring the Chinese City: Changing Society, Economy and Space, L. J. C. Ma and F. Wu (eds.). New York: Routledge.

Stead, D. 2001. Relationships between land use, socioeconomic factors, and travel patterns in Britain. Environment and Planning B 28(4): 499-528.

Stough, R. R. 2004. Institutions, land use and transportation. In Handbook of Transport Geography and Spatial Systems, D. A. Henscher, K. J. Button, K. E. Haynes, and P. R. Stopher (eds.). London: Elservier.

Stough, R. R., and P. Rietveld. 1997. Institutional issues in transport system. Journal of Transport Geography 5(3): 207214.

Stough, R. R., and P. Rietveld. 2005. Institutional dimensions of sustainable transport. In Barriers to Sustainable Transport: Institution, Regulations and Sustainability, R. R. Stough and P. Rietveld (eds.). Oxford, UK: Spon Press

Transportation Research Board, 2009. The Effects of Compact Development on Motorized Travel, Energy Use, and CO2 Emissions. TRB Special Report 298. Washington DC.: The National Academies Press.

Wan Fang Co. 2001. Housing sell was 200.1 billion Yuan in 2001. Wan Fang Data (in Chinese).

Wang, Y., and A. Murie. 1999. Commercial housing development in urban China. Urban Studies 36(9): 1475-1494.

Wank, D. L. 1999. Producing property rights: strategies, networks, and efficiency in urban China's nonstate firms. In Property Rights and Economic Reform in China, J. C. Oi and A. G. Walder (eds.). Stanford. CA: Stanford University Press.

Wei, Y. D. 2001. Dencentralization, marketization and globalization: The triple process underlying regional development in China. Asian Geographer 20(1/2): 7-23. 
World Bank. 2007. An overview of China's Transport sector-2007, EASTE Working Paper No. 15: Transport, Energy and Mining Sector Unit, Sustainable Development Department East Asia and Pacific Region.

Xie, Y., and F. J. Costa. 1993. Urban planning in Socialist China: Theory and practice. Cities 10(2) 103-114.

Yao, Y., and W. Qin. 2008. 300,000 people dead from urban fog and traffic pollutants is major reason. Nanfang Weekly.

Zhang, T. 2000. Land market forces and government's role in sprawl: The case of China. Cities 17(2): 123-135.

Zhao, P. 2010. Sustainable urban expansion and transportation in a growing megacity: Consequences of urban sprawl for mobility on the urban fringe of Beijing. Habitat International 34(2): 236-243.

Zhao, P. 2011. Managing urban growth in a transforming China: Evidence from Beijing. Land Use Policy 28(1): 96-109.

Zhao, P., and B. Lu. 2009. Transportation implications of the metropolitan spatial planning in megacity Beijing. International Development and Planning Review 31(3): 235-261.

Zhao, P., and B. Lu. 2010. Exploring job accessibility in the transformation context: An institutionalist approach and its application in Beijing. Journal of Transport Geography 18(3): 393-401.

Zhao, P., B. Lu, and G. de Roo. 2010. Performance and dilemmas of urban containment strategies in the transformation context of Beijing. Journal of Environmental Planning and Management 53(2): 143-161.

Zhao, P., B. Lu, and J. Woltjer. 2009a. Conflicts in urban fringe in the transformation era: An examination of performance of the metropolitan growth management in Beijing. Habitat International 33(4): 347-356.

Zhao, P., B. Lu, and J. Woltjer. 2009b. Growth management and decentralisation: An assessment of urban containment policies in the transformation era in Beijing. International Development Planning Review 31(1): 55 80.

Zhou, Y., and L. J. C. Ma. 2000. Economic restructuring and suburbanization in China. Urban Geography 21(3): 205236. 